\title{
Sustainable CONCEPT FOR GREen LOGISTICS AND ENERGY EFFICIENCY IN MANUFACTURING
}

\author{
MicieTA, B.; ZAVODSKA, L.; RAKYTA, M. \& BinASOVA, V.
}

Abstract: In this paper the authors present and discuss results of the development trends to achieving sustainability in logistics systems. The obtained results demonstrate the integration of energy efficiency in manufacturing and green logistic. Sustainable concept for green logistics and energy efficiency in manufacturing focuses on ecological, economic and social aspects. New energy efficient technologies can contribute to higher energy efficiency of enterprises. For automatic distribution of material in logistics process of manufacturing enterprise are used automatic logistics systems. These systems improve efficiency of logistics processes while decrease logistics costs. The further research will include the development in area of clean technologies, therefore the significant terms in the area of environmental and energy sustainability in logistics systems is defined.

Key words: Green logistics, sustainable production, cost optimization, energy efficiency, clean technologies
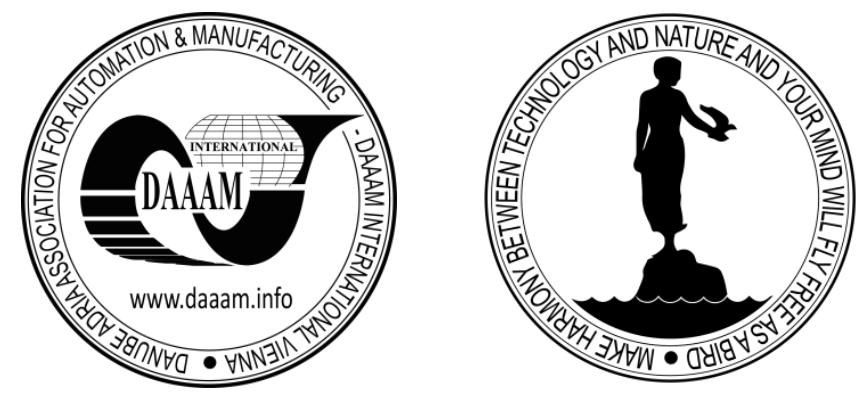

Authors' data: Prof. Ing. PhD. Micieta, B[ranislav]; Ing. Zavodska; L[udmila]; doc. Ing. PhD. Rakyta, M[iroslav], Ing. PhD. Binasova, V[ladimira], University of Zilina, Faculty of Mechanical Engineering, Univerzitna 8215/1, 01 026, Zilina, Slovakia, branislav.micieta@fstroj.uniza.sk, ludmila.zavodska@fstroj.uniza.sk, miroslav.rakyta@ fstroj.uniza.sk, vladimira.binasova@fstroj.uniza.sk

This Publication has to be referred as: Micieta, B[ranislav]; Zavodska, L[udmila]; Rakyta, M[iroslav] \& Binasova, V[ladimira] (2015). Sustainable Concept for Green Logistics and Energy Efficiency in Manufacturing, Chapter 33 in DAAAM International Scientific Book 2015, pp.391-400, B. Katalinic (Ed.), Published by DAAAM International, ISBN 978-3-902734-05-1, ISSN 1726-9687, Vienna, Austria DOI: $10.2507 /$ daaam.scibook.2015.33 
Micieta, B.; Zavodska, L.; Rakyta, M. \& Binasova, V.: Sustainable Concept for Gre...

\section{Introduction}

The green logistics means sustainable ecological orientation in logistics processes. Measuring and controlling the energy efficiency in manufacturing processes is the first step for evaluating and implementing of improvement measures.

New energy efficient technologies and clean technologies can contribute to higher energy efficiency of enterprises. Energy efficient logistics is also called green logistics. Concern for the environment is still increasing, so enterprises must take into account the costs related to ensuring of logistics, which is environmentally friendly. When we extend environment with the society as a whole, it is possible to speak about sustainable logistics.

This paper is structured in the form of five main sections. The first section discusses the introduction to area of green logistics and energy efficiency in manufacturing. Authors emphasize new energy efficient technologies in logistics processes. The second section outlines the problem statement of green logistics systems that can reduce transportation costs. The following third section covers the overview of green logistics and energy efficiency in manufacturing. The fourth section discusses in turn the achieved results and benefits of implementation energy-efficient technologies. There are also proposed key performance indicators enabled energy efficiency in manufacturing. The fifth section discusses the need of adaptive system and future research in this area for reducing energy intensity of logistics processes.

The main findings are then summarized in the conclusion.

\section{Problem statement of green logistics systems}

Energy efficiency in industry plays key role in improving energy security, environmental sustainability and economic performance. The evidence of great potential for cost-effective efficiency derived reduction in industrial energy use has prompted governments to implement numerous policies and measures aimed at improving their energy efficiency. The energy use is influenced by its many different technologies, processes and products, energy sources and prices, political, economic and business situations and making paradigms. To date numerous plant asset and maintenance management approaches target to increase the performance of the production system by eliminating waste, but managing energy in an efficient and effective way is not considered in most of these models or only plays a minor role (Gram \& Künstle, 2011). When we extend environment with the society as a whole it is possible to speak about sustainable logistics. When we integrated energy use and sustainable green logistics, we can create contribution of energy efficiency in manufacturing and green logistics (Fig. 1).

Manufacturing sustainability is addressed in this special issue with respect to:

- circular economy paradigm, fault-tolerance to disturbances,

- energy efficiency at resource and shop floor level,

- balancing resource usage; cost efficiency and in line quality control of products.

Innovative services will be enablers and drivers of growth of next generation of manufacturing enterprises that are competitive and sustainable. The use of materials is 
optimal, each type of waste is reused by other organisms and energy needs will be met using renewable sources such as solar energy (Bubeník \& Rakyta, 2014). The most frequently quoted definition of "Sustainable development" is from Our Common Future, also known as the Brundtland Report (WCDE, 1987): Sustainable development is development that meets the needs of the present without compromising the ability of future generations to meet their own needs. It contains within it key concept - the idea of limitations imposed by the state of technology and social organization on the environment's ability to meet present and future needs.

Decision making and implementation of the energy saving measures are based on the condition of the system, so technical and economic feasibility and important to balance these two important facts to arrive an optimum point. Reduce energy expenditure via a structured approach to identifying, measuring and managing energy consumption. Energy efficiency improvements in logistics processes are attainable with the best available technology and practice.

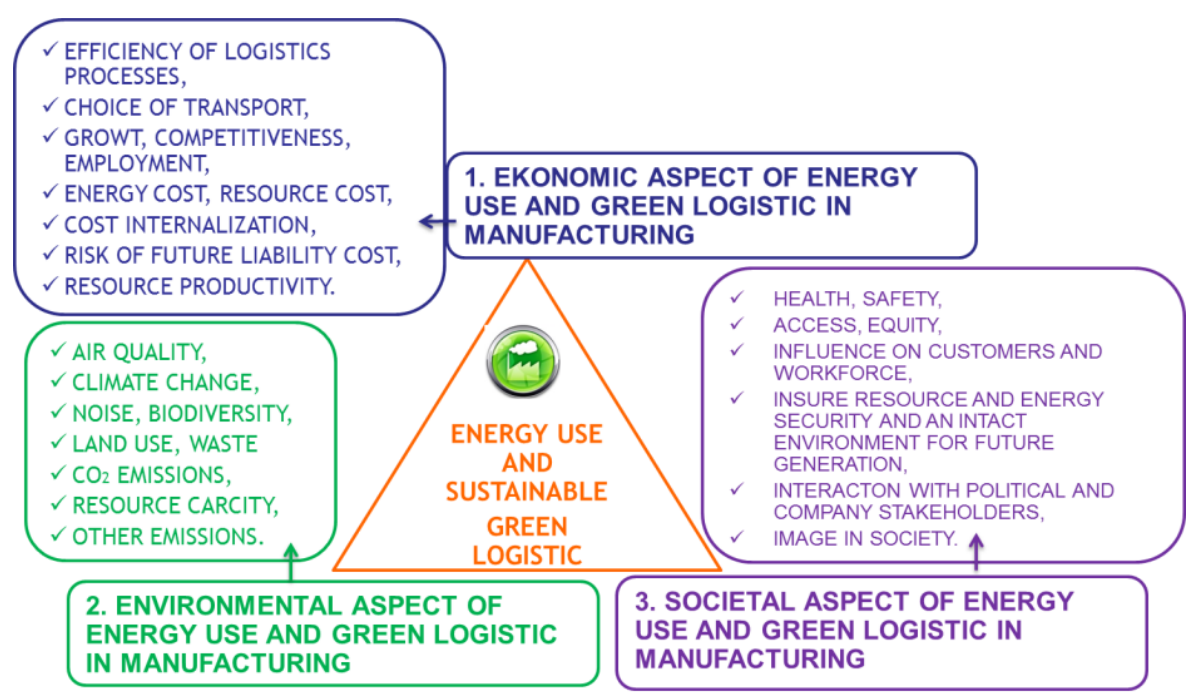

Fig. 1. Contribution of energy efficiency manufacturing and green logistics to the three main aspects of sustainable manufacturing

Energy efficient can pay for themselves in energy savings, sometimes within months, and further reduce operation and maintenance costs in the long term. The present development of new industrial machines which require higher efficiency and cost savings must provide a possibility of higher loadings, higher operating speeds and high reliability with fewer requirements for maintenance (Faturík et al., 2014).

New requirements generate pressure on various aspects of production. For example, it becomes increasingly important to produce more in less time at even lower costs (Gastermann et al., 2012). The efforts to reduce energy consumption are most frequently concentrating on a use of more efficient or more effective lighting systems that would meet required lighting technical parameters. It is generally accepted that more effective transfer of electricity into a visible light requires more expensive lamps and related additional investment costs (Kralikova et al., 2014). The energy management program is the important part of the satisfying any industrial production (Mihelic-Bogdanic \& Budin, 2011). In the development of technology is important to 
Micieta, B.; Zavodska, L.; Rakyta, M. \& Binasova, V.: Sustainable Concept for Gre...

ensure that energy consumption is as low, as it can. It is not an easy task, therefore, an attempt is designed information technology and hardware across any technology or equipment so that the least energy consuming (Micieta \& Binasova, 2014).

\section{Overview of green logistics and energy efficiency in manufacturing}

In the time of rapid changes in customer demand is necessary to flexibly react to customer requirements (Dulina \& Bartánusová, 2014). Tomorrow's energy efficient manufacturing will require additional processing power at all levels of its infrastructure. Most wireless sensor nodes presently powered by batteries: battery replacement is costly, self-powered sensors and actuators offer maintenance-free lifecycles and are environment-friendly. Currently, energy efficiency has gained significant attention from both academia and the industry due to the environmental and economic impacts associated with consumption of energy (Bunse et al., 2011).

The European Commission with the objective to reduce annual consumption of primary energy by $20 \%$ by 2020 , for example, estimates that an energy saving potential for the manufacturing sector of $25 \%$ could be realized by measures such as implementing energy efficient motors, fans and lightings. From the manufacturing companies' point of view, there are three important drivers to introduce energy efficiency improvements:

- rising energy prices (Hnát, 2013),

- customers changing their purchasing behaviour with regard to "green" and energy efficient products and services (Chittyal et al., 2013),

- new environmental regulations with their associated costs for $\mathrm{CO}_{2}$ emissions.

The newest development paradigm in field of adaptation to production requirements are reconfigurable manufacturing systems (RMS) and reconfigurable assembly systems (RAS). From the perspective of sustainability, the relevant objectives of RMS are:

- to reduce the wastes through the reuse of manufacturing resources,

- to reduce energy cost through the optimization of manufacturing processes and system reconfiguration (Micieta, et al. 2013).

There are other directions of success in the future:

- Energy efficiency in manufacturing will more and more move into consulting and service area at the expense of traditional production (research and development services, services related to the use of information and communication technologies, management consulting, services related to enterprise management).

- Significant development of virtual reality and digital factory, their integration into design phase, doing process optimization in laboratory conditions. The following implementation in an industrial environment is very fast (Krajčovič et al., 2013).

- Another change or direction is a question of a new form of cooperation (Kohár \& Hrček, 2014).

- In the future, more use of operation research techniques to advance the base of PC models for the analysis of manufacturing and service problems. 
With the expansion of e-business, enterprises will need more advanced and accurate techniques for predicting the energy outputs. These techniques are based on computer simulation (Mičieta \& Stollmann, 2011), (Mičietová et al., 2013).

The integration of man and his knowledge base in manufacturing processes. Even if an effective monitoring and control mechanism is in place, managers may have difficulties evaluating the impact and effects of energy efficiency improvement measures because of the lack of appropriate concepts for evaluation:

- evaluation of new or alternative concepts to increase efficiency considering the cost involved (Rakyta \& Fusko, 2015); this allows for transparency and identification of energy intensive components, e.g. in logistics systems,

- new management concepts to derive appropriate energy efficiency improvement strategies (Magvaši \& Gregor, 2013),

- development of a cost calculation tool including 'resource and energy-cost', in order to make these costs transparent to the customer,

- assessment of the relationship between different manufacturing processes as improvement in one process could potentially negatively impact another part of the value stream with regard to energy efficiency (Micieta \& Binasova, 2014).

\subsection{The green logistics}

Sustained efforts to protect the environment and resources, of course bring costs. Investing in planning processes and in new processes and technologies is associated with short-term to medium-term higher costs for logistics. However, economies of scale and competitive advantages arise. This applies particularly to sections with a high degree of automation. Processes improved from the aspects of sustainability not only provide optimized use and saving but also can be presented to the customers and the public, thus can be improved the enterprise image.

There is created new structure of energy efficient logistics, as is shown in Fig. 2. In this six levels should be implemented measures for protecting the environment, resources and ability energy planning of energy consumption in logistics processes.

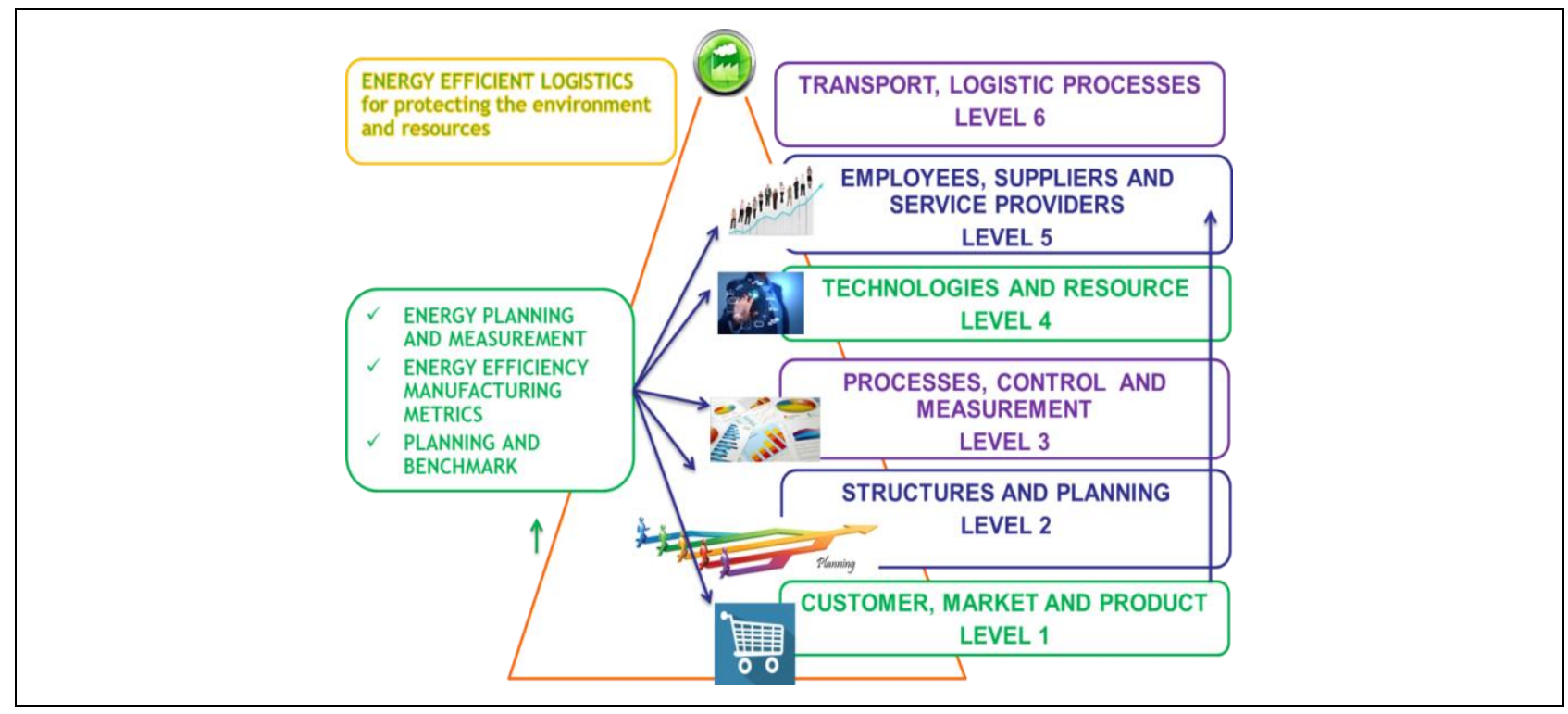

Fig. 2. Structure of energy efficient logistics 
Micieta, B.; Zavodska, L.; Rakyta, M. \& Binasova, V.: Sustainable Concept for Gre...

\section{Methods use and results - Key Performance Indicators (KPIs)}

By establishing production information systems towards energy efficiency, decision makers will be provided with relevant information on impacts on energy performance resulting from production planning and business decisions. In the interviews and the workshops with industry representatives it became evident, that there is a need for energy efficiency KPIs to track the changes and improvements on both process and on plant level.

Industry seems to lack the means and appropriate KPIs to compare energy usage profiles of machines and processes and to compare their energy efficiency performance to other enterprises. One of key internal energy factor of production productivity is employee.

Employees should be provided with the most efficient modern methods and energy efficient equipment. Key needs expressed by the interviewees in the area of measurement of energy efficiency include KPIs (Fig. 3).
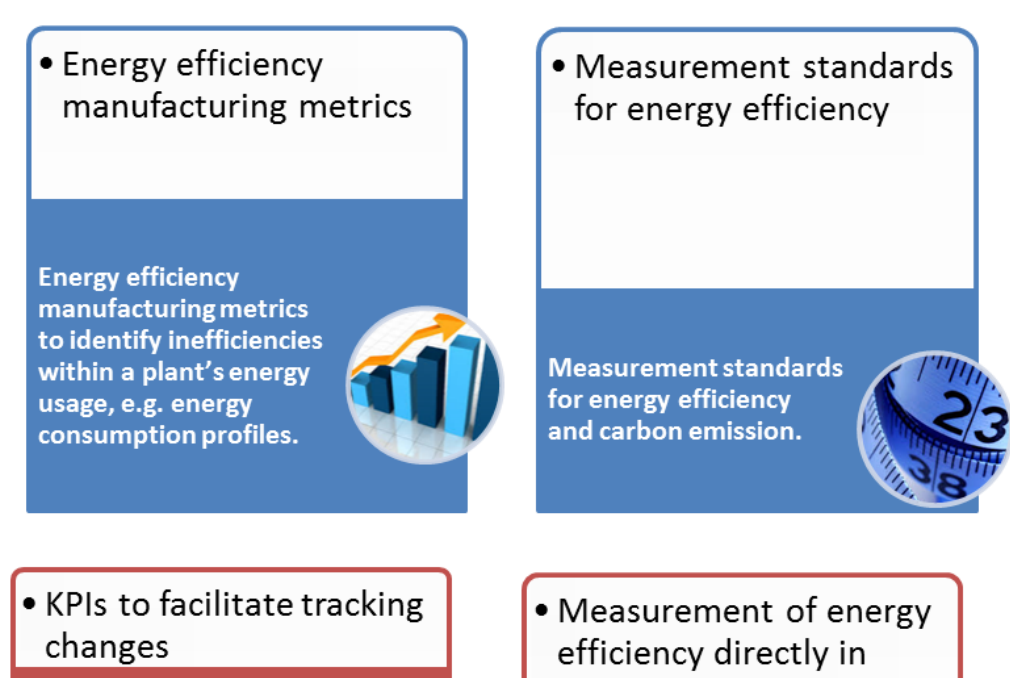

\section{KPls to facilitate}

tracking changes and

improvements in energy

efficiency. By making

energy efficiency

improvements,

company can reduce its

consumption of fossil

fuels and its

contribution to the

emission, etc.

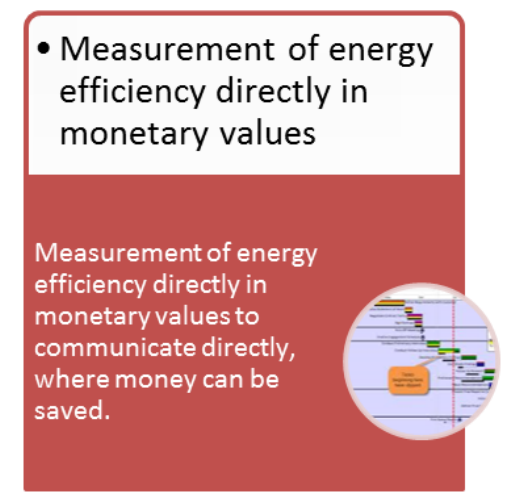

- Standardization of environmental performance metrics including energy efficiency KPIs

As to energy efficiency metrics and environmental KPIs, a

wide range of such

indicators has been

developed over the past decade.

\section{- Map energy usage for better understanding inputs and outputs.}

Development of

processes to map

energy usage for better

understanding input,

output and

measurement points for

each manufacturing

process.

Fig. 3. Key needs expressed by the interviewees in the area of measurement of energy efficiency

Some innovations may primarily be aimed at one goal, but also generally include beneficial impacts on other aspects of a production process. Certain technologies that are identified as being energy-efficient, because they reduce the use of energy will bring a number of additional enhancements to the production process. These improvements of non-energy benefits beyond energy savings potential are shown in Fig. 4. 


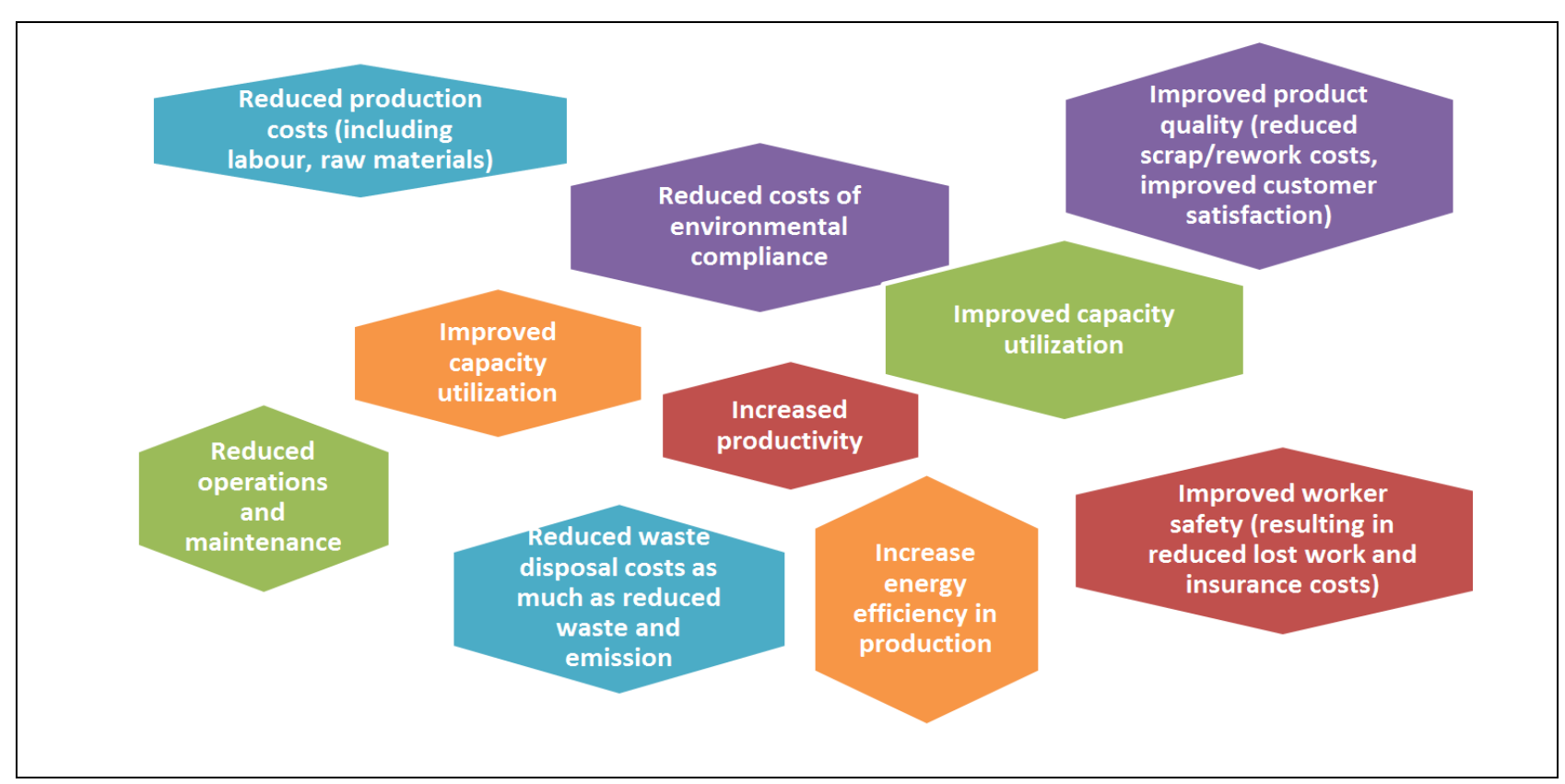

Fig. 4. Energy benefits of energy-efficient technologies

\section{Future research plans}

For automatic distribution of material in logistics process of manufacturing enterprise are used automatic logistics systems. They increase automation and productivity of logistics and contribute to reducing business costs. Automatic guided vehicle (AGV) system automates pulling wagons with material by a predefined path with the help of logistics trucks in industrial halls (Fig. 5). System as a whole improves efficiency of logistics processes while decrease logistics costs.

This system uses the logistics towing units Aurora, from the company CEIT (Central European Institute of Technology, Zilina), (Grznár \& Hnát, 2014).

These autonomous towing units were developed in the base of the requirements of the automotive industry, in cooperation with Volkswagen, Slovakia. The resulting solution is the Modular reconfigurable logistics system. As is shown in Fig. 5, the system uses automatic identification of towing units position, custom navigation, monitoring and control system, which is integrated to the production planning system. One of the main benefits of the AGV is reducing costs by reducing work-in-process, as well as cost savings for employees who are required to operate the truck by manual logistics.

Calculations from a case study of employees University of Zilina show that the total annual costs of manual logistics are $182160 €$ while total annual costs of implementation AGV are $89456 €$.

The case study was conducted in conditions of subcontractors for the automotive industry, where for supplying was used three forklifts operated by employees.

Overall Equipment Effectiveness is a comprehensive manufacturing indicator designed to evaluate the efficiency of production, which can be implemented in AGV MCS (Monitor and Control System). The result of the analysis is to calculate and display an all-in indicator, which shows the overall efficiency of the device. 
Micieta, B.; Zavodska, L.; Rakyta, M. \& Binasova, V.: Sustainable Concept for Gre...

Future research plan is new energy solution for AGV. One of the opportunities is lower operating costs by using efficient energy storage. These systems offer 24-hour operation without battery changing, reduced charging times, minimum maintenance requirements and maximum operational flexibility.

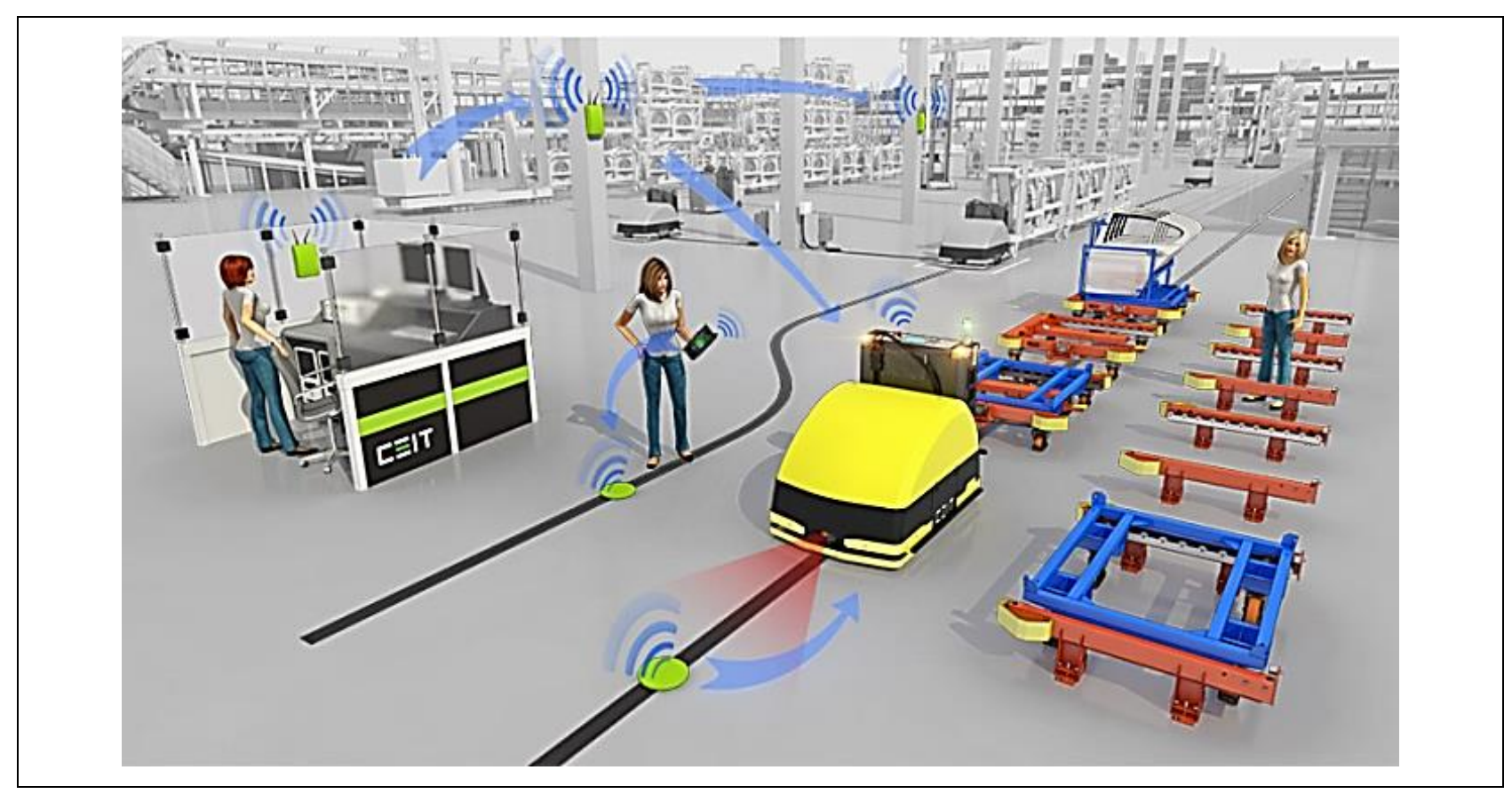

Fig. 5. AGV (Automated guided vehicle) system

\section{Conclusion}

Technological development is in fast progress and therefore enterprises have to think about which technologies to include to their strategies and how they will reach their defined goals in area of energy efficiency. Technological development is related to devices that are used to create an efficient material flow with positive effect on use of energy and with positive impact on environment.

Manufacturing converts a wide range of raw materials, components, and parts into finished goods that meet market expectations. Looking toward the future, businesses are taking a more standardised approach and respecting the importance that labelling solutions play in logistics processes.

Nowadays, green logistics and energy efficiency in manufacturing are very important form optimization of logistics processes. New energy efficient technologies as modular reconfigurable logistics system are developed at University of Zilina. These AGV can break energy regeneration, wireless monitoring and control system, unattended operation, automatic charging, truck modularity and standardized modules.

The problem statement of green logistics systems and the overview of green logistics and energy efficiency in manufacturing are also described. The key performance indicators enabled energy efficiency in manufacturing are a set of quantifiable measures, agreed to beforehand, that an industry uses to gauge or compare performance in terms of meeting their strategic and operational goals. This indicator is very important to evaluate the energy efficiency of logistics process. 
Energy efficiency in logistics processes are achieved by use of an energy management system which presents various strategies, tools, methods, technologies, and effective measures to face energy saving and consumption issues, that also includes energy audits, monitoring, control and continuous improvement of the system. It can be also achieved by use of automatic logistics systems.

Key needs in the area of measurement of energy efficiency include KPIs can help to improve this logistics processes. The energy benefits of energy-efficient technologies were verified on this AGV system in Zilina Intelligent Manufacturing System (ZIMS).

The ambition of future research work and project is to design and develop a new practical concept of reconfigurable logistics system and on its prototype check the possibilities of its putting in the automotive and electronics in industry.

\section{Acknowledgements}

This paper is the part of research supported by project VEGA 1/0559/15.

\section{References}

Bubeník, P. \& Rakyta, M. (2014). Data mining technology and its benefits in business practice, In: Manufacturing systems today and tomorrow 2014, Liberec, ISBN 978-807494-150-4

Bunse K., et al. (2011). Integrating energy efficiency performance in production management-gap analysis between industrial needs and scientific literature. In: Journal of Cleaner Production. ISSN: 0959-6526

Chittyal, V. R. et. al., (2013). Green Logistics. IJRMBSS I ISSN 2319-6998, Vol. 1, In: Indian Journal of Research in Management, Business and Social Sciences (IJRMBSS)

Dulina, L. \& Bartánusová, M. (2014). CAVE design using in digital factory, Proceedings of Procedia Engineering: international symposium on intelligent manufacturing and automation, Katalinic, B. (Ed.), DAAAM 2014, Vol. 100, pp. 291298, ISSN 1877-7058, Vienna

Faturík, L. et al. (2014). Comparison of structural design in high and ultra-high cycle fatigue regions. In: Transactions of FAMENA, Vol. 38, no. 4 (2014), pp. 1-12, ISSN $1333-1124$

Gastermann, B. C., Stopper, M. \& Katalinic, B. (2012). Adapting CONWIP Characteristics for Conventional Production Planning. In DAAAM International Scientific Book 2012, pp. 553-564, Editor B. Katalinic, Publisher by DAAAM International, ISBN 978-3-901509-86-5, Vienna, Austria

Gram, M. \& Künstle, S. (2011). Effiziente Produktion durch Vermeidung der Verlustquellen im Anlagenbetrieb - Identifizierte Verlustquellen in Produktion und Instandhaltung und deren Einfluß auf die eingesetzten Produktionsfaktoren. Lean Maintenance. H. Biedermann 
Micieta, B.; Zavodska, L.; Rakyta, M. \& Binasova, V.: Sustainable Concept for Gre...

Grznár, P. \& Hnát, J. (2014). Automation of production logistics, In: ProIN. Vol. 15, No. 1, pp. 36-37, ISSN 1339-2271

Hnát, J. (2013). Assembly line balancing problem solved by genetic algorithm, In: AIE: monograph, Bielsko-Biała, pp. 7-8, ISBN 978-83-927531-6-2

Kohár, R. \& Hrček, S. (2014). Dynamic analysis of a rolling bearing cage with respect to the elastic properties of the cage for the axial and radial load cases, In: Communications, Vol. 16, no. 3A (2014), pp. 74-81, ISSN 1335-4205

Krajčovič, M. et al. (2013). Intelligent manufacturing systems in concept of digital factory. In: Communications, Vol. 15, No. 2, pp. 77-87, ISSN 1335-4205

Kralikova, R. et al. (2014). Energy Saving Techniques and Strategies for Illumination in Industry. Proceedings of Procedia Engineering: international symposium on intelligent manufacturing and automation, Katalinic, B. (Ed.), DAAAM 2014, Vol. 100, pp. 291-298, ISSN 1877-7058, Vienna

Magvaši, P. \& Gregor. M. (2013). Advanced industrial engineering and quality of industrial enterprises. In: Quality of Products from the quality of responsibility and innovation, pp. 38-42, ISBN 978-80-553-1466-2, Kosice

Micieta, B. \& Binasova, V. (2014) Methodology of implementation energy efficiency in manufacturing. In: DAAAM international scientific book 2014. Vienna: DAAAM International Vienna, 2014. ISBN 978-3-901509-98-8. pp. 357-364, Scientific book. ISSN 1726-9687

Micieta, B. \& Binasova, V. (2013). Defining requirements for energy efficiency in manufacturing. In: DAAAM international scientific book 2013. Vienna: DAAAM international Vienna. ISBN 978-3-901509-94-0. pp. 887-894

Mičieta, B. \& Stollmann, V. (2011). Assembly Line Balancing. In DAAAM International Scientific Book 2011, pp. 257-264, Editor B. Katalinic, Publisher by DAAAM International, ISBN 978-3-901509-84-1, ISSN 1726-9687, Vienna, Austria Micieta, B. et al. (2013). Definition of the requirements in order to achieve sustainable production. In: European international journal of science and technology. ISSN 23049693. Vol. 2, No. 4, online, pp. 125-130. Online: http://www.cekinfo.org.uk/images/frontImages/gallery/Vol._2_No._4_/13.pdf

Mičietová, A. et al. (2013). Analysis of high and low frequency Barkhausen noise for detection grinding burn. Proceedings of international congress on engineering and technology, pp. 27-38, ISBN 978-80-87670-08-8, 2013, RISE Association, Prague Mihelic-Bogdanic, A. \& Budin, R. (2011). Effective energy management in polyethylene production. In: DAAAM international scientific book 2011. Vienna: DAAAM international Vienna. ISBN 978-3-901509-84-1, ISSN 1726-9687. pp. 063070

Rakyta, M. \& Fusko, M. (2015). Increasing quality of production. In: Technológ. ISSN 1337-8996. Vol. 7, No. 3, pp. 78-81

Staszewska, J. (2013). The company Industrial towards the challenges of the twentyfirst century. Krakow and Warsaw: Unique, 2013. ISBN 978-83-62314-80-5 (in Polish)

WCED, (1987). World Commission on Environment and Development: Our common future, p. 43. Oxford University Press, Oxford 